\begin{tabular}{|l|l|l||}
\hline \multicolumn{2}{|c|}{ PublisherInfo } \\
\hline \hline PublisherName & $:$ & BioMed Central \\
\hline \hline PublisherLocation & $:$ & London \\
\hline \hline PublisherImprintName & $:$ & BioMed Central \\
\hline \hline
\end{tabular}

\title{
Articles selected by Faculty of 1000: chromosomal rearrangements and mental retardation; peptide-MHC microarrays; antimicrobial drug discovery; core set of Arabidopsis accessions; comparing mouse development and human tumorigenesis
}

\begin{tabular}{|l|l|l||}
\hline \multicolumn{2}{|c||}{ ArticleInfo } \\
\hline \hline ArticleID & $:$ & 3487 \\
\hline \hline ArticleDOI & $:$ & $10.1186 /$ gb-2004-5-5-326 \\
\hline \hline ArticleCitationID & $:$ & 326 \\
\hline \hline ArticleSequenceNumber & $:$ & 21 \\
\hline \hline ArticleCategory & $:$ & Paper report \\
\hline \hline ArticleFirstPage & $:$ & 1 \\
\hline \hline ArticleLastPage & $:$ & 3 \\
\hline \hline ArticleHistory & $:$ & RegistrationDate : 2004-4-27 \\
\hline
\end{tabular}




\begin{tabular}{|c|c|c|}
\hline & OnlineDate & : 2004-4-27 \\
\hline ArticleCopyright & \multicolumn{2}{|c|}{ BioMed Central Ltd2004 } \\
\hline ArticleGrants & & \\
\hline ArticleContext & 130595555 & \\
\hline
\end{tabular}

The Author(s)

\section{Summary}

A selection of evaluations from Faculty of $\mathbf{1 0 0 0}$ covering chromosomal rearrangements and mental retardation, peptide-MHC microarrays, antimicrobial drug discovery, a core set of Arabidopsis accessions and comparing mouse development and human tumorigenesis.

\section{Chromosomal rearrangements and mental retardation}

Genomic imbalances in mental retardation. Kriek M, White SJ, Bouma MC, Dauwerse HG, Hansson KB, Nijhuis JV, Bakker B, Van Ommen GJ, Den Dunnen JT, Breuning MH. J Med Genet 2004, 41:249-255.

For the Faculty of 1000 evaluation of this article please see: http://genomebiology.com/reports/F1000/ gb-2004-5-5-326.asp\#Kriek

\section{Peptide-MHC microarrays}

Detection and characterization of cellular immune responses using peptide-MHC microarrays. Soen Y, Chen DS, Kraft DL, Davis MM, Brown PO. PLoS Biol 2003, 1:E65.

For the Faculty of 1000 evaluation of this article please see: http://genomebiology.com/reports/F1000/ gb-2004-5-5-326.asp\#Soen 


\section{Antimicrobial drug discovery}

Antimicrobial drug discovery through bacteriophage genomics. Liu J, Dehbi M, Moeck G, Arhin F, Bauda P, Bergeron D, Callejo M, Ferretti V, Ha N, Kwan T, et al. Nat Biotechnol 2004, 22:185-191.

For the Faculty of 1000 evaluation of this article please see: http://genomebiology.com/reports/F1000/ gb-2004-5-5-326.asp\#Liu

\section{Core set of Arabidopsis accessions}

Nested core collections maximizing genetic diversity in Arabidopsis . McKhann HI, Camilleri C, Bérard A, Bataillon T, David JL, Reboud X, Le Corre V, Caloustian C, Gut IG, Brunel D. Plant J 2004, 38:193-202.

For the Faculty of 1000 evaluation of this article please see: http://genomebiology.com/reports/F1000/ gb-2004-5-5-326.asp\#McKhann

\section{Comparing mouse development and human tumorigenesis}

Conserved mechanisms across development and tumorigenesis revealed by a mouse development perspective of human cancers. Kho AT, Zhao Q, Cai Z, Butte AJ, Kim JY, Pomeroy SL, Rowitch DH, Kohane IS. Genes Dev 2004, 18:629-640.

For the Faculty of 1000 evaluation of this article please see: http://genomebiology.com/reports/F1000/ gb-2004-5-5-326.asp\#Kho

This PDF file was created after publication. 